\title{
A Novel Energy Management Strategy for a Ship's Hybrid Solar Energy Generation System Using a Particle Swarm Optimization Algorithm
}

\author{
Rui Yang ${ }^{1,2}$, Yupeng Yuan ${ }^{1,3,4, * \mathbb{C}}$, Rushun Ying ${ }^{1}$, Boyang Shen ${ }^{3}{ }^{(0)}$ and Teng Long ${ }^{3}$ \\ 1 Reliability Engineering Institute, School of Energy and Power Engineering, Wuhan University of Technology, \\ Wuhan 430063, Hubei, China; yangr@wti.ac.cn (R.Y.); Rosentinel@163.com (R.Y.) \\ 2 China Water Transport Research Institute, Beijing 100089, China \\ 3 Department of Engineering, University of Cambridge, Cambridge CB3 0FA, UK; bs506@cam.ac.uk (B.S.); \\ t1322@cam.ac.uk (T.L.) \\ 4 National Engineering Research Center for Water Transport Safety, Wuhan University of Technology, \\ Wuhan 430063, Hubei, China \\ * Correspondence: ypyuan@whut.edu.cn
}

Received: 17 December 2019; Accepted: 9 March 2020; Published: 16 March 2020

\begin{abstract}
Due to the pressures caused by the energy crisis, environmental pollution, and international regulations, the largest ship-producing nations are exploring renewable resources, such as wind power, solar energy, and fuel cells to save energy and develop more environmentally-friendly ships. Solar energy has recently attracted a great deal of attention from both academics and practitioners; furthermore, the optimization of energy management has become a research topic of great interest. This paper takes a solar-diesel hybrid ship with 5000 car spaces as its research object. Then, following testing on this ship, experimental data were obtained, a multi-objective optimization model related to the ship's fuel economy and diesel generator's efficiency was established, and a partial swarm optimization algorithm was used to solve a multi-objective problem. The results show that the optimized energy management strategy for a hybrid energy system should be tested under different electrical loads. Moreover, the hybrid system's economy should be taken into account when the ship's power load is high, and the output power from the new energy generation system should be increased as much as possible. Finally, the diesel generators' efficiency should be taken into consideration when the ship's electrical load is low, and the injection power of the new energy system should be reduced appropriately.
\end{abstract}

Keywords: solar energy; hybrid solar energy generation system; energy management strategy; partial swarm optimization algorithm; multi-objective optimization

\section{Introduction}

Shipping is one of the most economical transportation methods and it plays an important role in the development of the world's economy. However, due to increases in the volume of world trade and energy demands, the environmental pollution associated with shipping has become increasingly acute. At present, $90 \%$ of the world's cargo is transported by bulk ships [1]. These large-scale, ocean-going vessels use a lot of fuel, and emit large amounts of environmentally harmful gases (e.g., NOX, SOX, $\mathrm{CO} 2$, and $\mathrm{CO}$ ) and particulate matter [2].

These emissions not only cause atmospheric pollution, but also have a serious impact on people's health [3]. Therefore, international organizations are constantly issuing instructions to limit the discharge of ships [4]. Faced with the global energy crisis and increasingly stringent regulatory requirements, shipping companies are actively seeking novel and efficient strategies (i.e., 
the development and utilization of clean energy) to save energy and reduce the emissions from ships. Solar energy is a well-known type of clean and renewable energy. Moreover, the use of solar energy to supply a ship's electricity requirements and power for electric propulsion systems has a number of advantages, including decreases in a ship's fuel consumption and a reduction in emissions [5-7]. Furthermore, solar photovoltaic (PV) technology is becoming increasingly mature, and thus solar energy has broad application prospects for ships in the near future.

Currently, some developed countries (e.g., European and North American countries), as well as China, are developing technologies related to the design and manufacture of solar ships. These studies have mainly focused on the integrated design of solar energy systems [5-7], energy conversion devices [8], energy management systems [9], optimization and matching of system parameters [10,11], and maximum power point tracking (MPPT) [12], and some significant results have been achieved. However, when a ship's existing solar system is studied, the characteristics of a ship's electrical load are a major consideration. A key issue when designing a solar-diesel hybrid ship is how to optimize the power output of the solar collectors and diesel generators in order to meet the needs of the entire ship's electricity load, so that the economic efficiency of its fuel is optimal and the generator also remains highly efficient.

With regard to energy management strategies for solar-diesel hybrid systems on land, several researchers have conducted extensive studies on the design $[13,14]$, modeling, control and simulation [15-17], experimental performance [18], optimal management of hybrid power systems [19-23], optimum size of hybrid power systems [24], advanced controller design [25], and optimal operation of hybrid energy systems [26]. However, few studies have concentrated on strategies for energy management in solar-diesel hybrid ships. Liu et al. [27] investigated a solar-diesel hybrid ship consisting of solar energy, a storage battery, and a super capacitor. By establishing a mathematical model of the ship's movement, the characteristics of the solar power output were studied, and a method for suppressing its fluctuation using a dual-energy storage system was developed. Moreover, Guo et al. [28] proposed a load-flow calculation method for solar energy, a diesel generator, and battery hybrid ships, and also carried out a numerical simulation. Their results provided a theoretical basis for improving the stable and flexible output of PV systems. Kenan et al. [29] designed a hybrid energy ship for a shore power system and also proposed a new energy management strategy. Through an analysis of five cases, it was proved that the proposed energy management strategy could achieve energy savings and a reduction in emissions. Cao et al. [30] designed a solar-diesel hybrid system for the high energy consumption of the vapor compression cycle of a cruise ship's air-cooled equipment. A control strategy was established under three cabin cooling conditions, which effectively reduced the emission of greenhouse gases. Park et al. [31] and Lan et al. [32] focused on solar-diesel hybrid ships, using batteries and flywheels, respectively, in order to smooth the fluctuation of the solar output power caused by environmental factors. Based on the experimental data of a PV system, a numerical analysis was carried out, with the results showing that the proposed method could effectively reduce a ship's fuel consumption. Divyajot et al. [33] and Zhang et al. [34] designed an energy management controller for a hybrid ship composed of solar energy, an energy storage system and a diesel generator set, taking the demand power of the hybrid system as the input and the power of the DC bus as the output. Particle swarm optimization (PSO) was used to solve the problem while meeting the goal of minimum fuel consumption. Simulation results showed that the energy management strategy optimized by PSO effectively reduced fuel consumption.

The studies above were all focused on energy management strategies designed for solar power stability or flexible output, and these methods can, to a certain extent, be effective for saving energy and reducing emissions. However, when the efficiency of solar and diesel generators under different sailing conditions is considered, the system's overall performance is not very efficient when the maximum amount of solar power is injected into the grid. For example, when a ship's electrical load is relatively low, if more power is injected into the grid, the fuel consumption of the overall system will decrease. However, this may cause the diesel generator to run for a long time under a low load, resulting in 
more wear of the engine parts, deteriorative effects of the combustion process on the environment, and a reduction in the lifetime of the engine.

Therefore, to resolve the aforementioned problems, this paper used a solar-diesel hybrid generator system on a ship as the research object, established a multi-objective optimization model with the ship's minimum equivalent specific fuel consumption and the diesel generator's maximum efficiency, and used the PSO algorithm to solve this multi-objective optimization problem. Consequently, the optimal output power of the solar energy under different power loads could be calculated. The novelty of this study is that the proposed energy management strategy takes both the ship's economy and the efficiency of the diesel generator into account, and it could reduce a ship's fuel consumption and increase the diesel generator's work life.

The paper is organized as follows: Section 2 introduces the system configuration of the ship and the solar-diesel hybrid generator system used in the study; Section 3 establishes a multi-objective optimization mathematical model of the ship's solar-diesel hybrid electrical generator system; Section 4 uses the PSO algorithm to solve a multi-objective problem; Section 5 presents the results of the analysis; and Section 6 draws the main conclusions of the paper.

\section{A Solar-Diesel Hybrid Electrical Generator System of a Ship}

This paper takes an offshore ocean vehicle roll-on roll off (ro-ro) ship as the research object, the basic parameters of which are presented in Table 1. Based on the ship's original power system, a large-scale on/off grid integrated solar power generation device was designed using a battery storage system, and then installed to form a solar-diesel generator hybrid power system (see Figure 1).

Table 1. The basic parameters of the roll-on roll off (ro-ro) ship.

\begin{tabular}{cccc}
\hline Overall length & $182.80 \mathrm{~m}$ & speed & $20.20 \mathrm{kn}$ \\
\hline Beam & $32.20 \mathrm{~m}$ & total deadweight tonnage & $14,759.06 \mathrm{t}$ \\
\hline Depth & $14.95 \mathrm{~m}$ & number of parking Spaces & 5000 pctc \\
\hline Design draft & $8.40 \mathrm{~m}$ & & \\
\hline
\end{tabular}

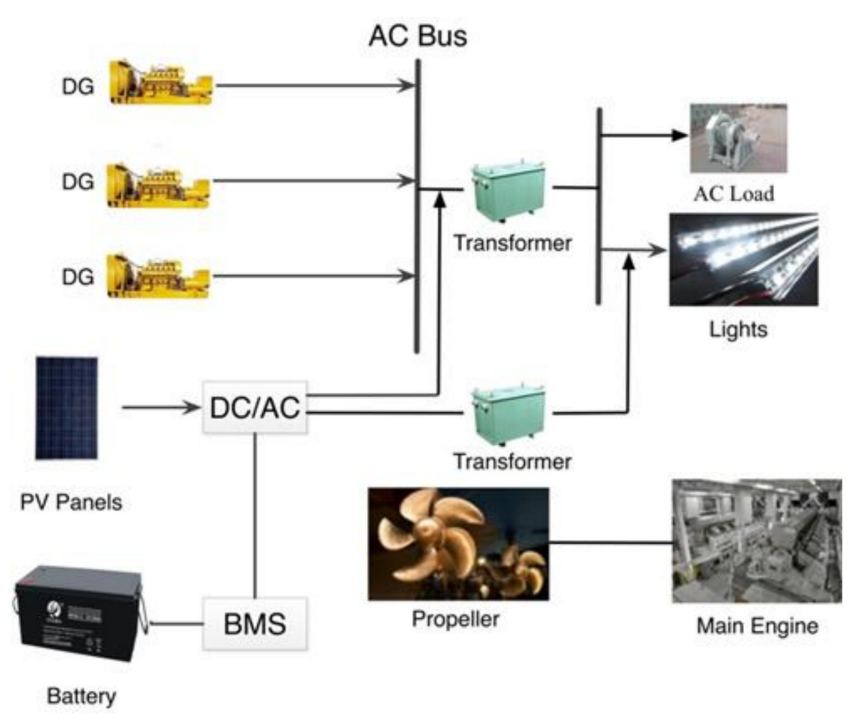

Figure 1. A flowchart of the solar-diesel generator hybrid system.

According to the measured data, the unobstructed area of the ship's upper deck is approximately $1300 \mathrm{~m}^{2}$. With regards to the needs of the maintenance channels, a solar PV system with a total capacity of $143 \mathrm{kWp}$ was installed. The solar module is a $400 \mathrm{~mm}$ series monocrystalline silicon solar panel, its peak power under standard test conditions is $265 \mathrm{~W}$, and it measures $1650 \times 990 \times 40 \mathrm{~mm}^{3}$ and weighs 
$19.1 \mathrm{~kg}$. According to the standard irradiance conditions $\left(1000 \mathrm{~W} / \mathrm{m}^{2}\right.$, panel temperature: $\left.20^{\circ} \mathrm{C}\right)$, 18 in-series and 30 in-parallel panels were used, accounting for a total of 540 solar panels.

The energy storage system uses a marine-use $3.2 \mathrm{~V} / 100$ Ah lithium-ion battery, which is composed of 120 units connected in-series and 17 strings in-parallel, resulting in a total of 2040 battery cells. The rated capacity is $652.8 \mathrm{kWh}$. The battery cell's output voltage is set up to be DC $384 \mathrm{~V}$. The energy storage system unit was designed according to the ship's actual requirements, while the thermal issues and protection under a high-temperature environment were also fully considered. The battery management system (BMS) is used to manage the battery pack.

Three diesel generators produced by YANMAR (Osaka, Japan) were installed on the ship, namely, two $1020 \mathrm{~kW}$ 6N21AL-GV diesel generators and one $960 \mathrm{~kW}$ 6N21AL-UV diesel generator. When the ship is sailing normally, one $1020 \mathrm{~kW}$ diesel generator is turned on. When the ship is arriving at, or departing from a port, both $1020 \mathrm{~kW}$ diesel generators are turned on. The $960 \mathrm{~kW}$ diesel generator is on standby, and is turned on when any of the $1020 \mathrm{~kW}$ engines do not work.

The schematic diagram of the hybrid electrical energy generation system after it was remodeled is shown in Figure 2. The system has four operating modes which can be manually selected:

1. During an off-grid operation, the PV modules charge the battery through the PV controller, and the battery and/or PV voltage is converted directly to AC $450 \mathrm{~V}$. After that, the voltage is stepped-down through a three-phase transformer and powers the load directly.

2. In a grid-connected operation, the PV modules charge the battery via the PV controller, and the energy of the battery and/or PV is fed back to the grid. To prevent current reverse in the ship's synchronous generator, a set of anti-backflow devices are equipped with a Busbar system.

3. When the PV system's output power drops sharply, and the battery's energy is insufficient to support the load, the bypass backup function is activated and the ship's electric power system is used to supply energy to the lighting load.

4. When a fault in the PV system occurs, the single-pole, double-throw switch is switched to the original ship's power grid and diesel generator sets to supply energy to the lighting load.

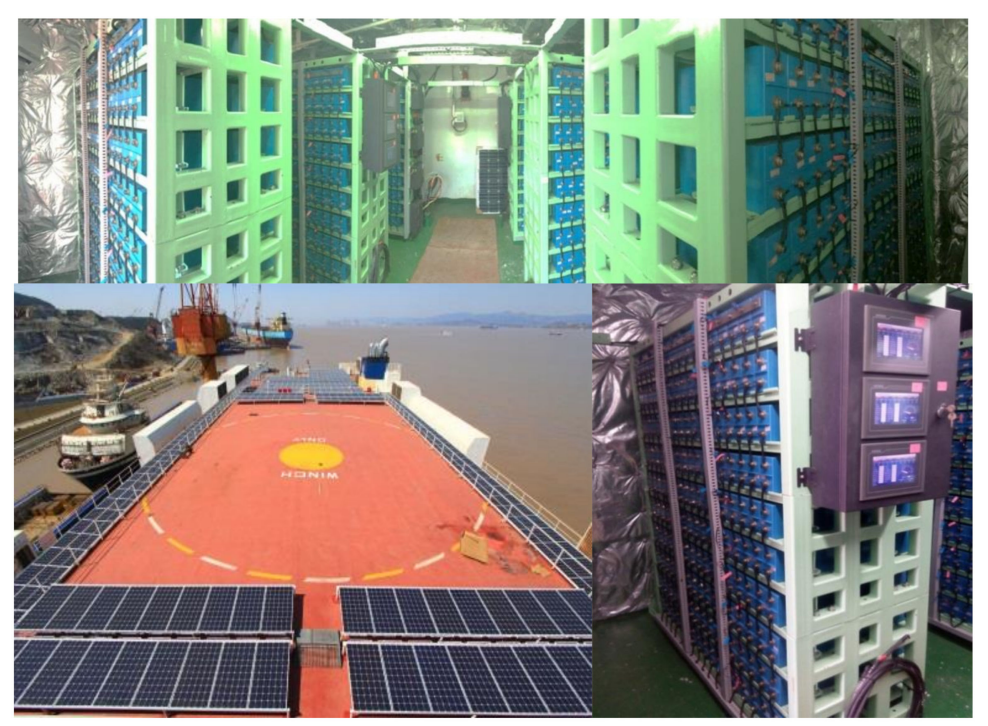

Figure 2. A schematic diagram of the remodeled hybrid electrical energy generation system.

\section{A Multi-Objective Optimization Model for Energy Management}

According to the operation mode of the solar-diesel generator hybrid system, when the system is operating in the off-grid mode, the solar PV system and battery system only provide power for cabin lighting, while the diesel generator provides power for other power loads. These are mutually independent power supply circuits, and their output power is only affected by the load fluctuation in 
their own circuits. Therefore, this study only discusses optimization related to energy management in the grid-connected mode.

With regard to the aforementioned solar-diesel generator hybrid system, one of the main objectives of the energy management strategy is to reduce the entire ship's fuel consumption. Since the battery is only charged by the solar PV system and a diesel generator does not charge the battery, when there is additional fuel consumption and new energy is injected into the power grid, the diesel generator's fuel consumption will reduce, however, its specific fuel consumption will increase as it is running at a low efficiency level. During the diesel generator's operation, its fuel consumption will increase due to the influences of vibration, friction and wear, the temperature of cooling water, and other factors. In order to facilitate the calculation and ignore the influence of the above factors, it is assumed that the diesel generator is always running in good technical condition. Therefore, the equivalent specific fuel consumption can be used to evaluate the economic advantages of hybrid systems [35].

$$
\widetilde{g}(t)=\frac{P_{D E}(t) \cdot g(t)}{P_{L}(t)}=\frac{\left(P_{L}(t)-P_{N}(t)\right) g(t)}{\eta(t) P_{L}(t)}=\frac{\sum_{i=1}^{n} \frac{P_{O_{i}}(t)}{\eta_{i}(t)} g_{i}(t)}{P_{L}(t)} i=1,2, \cdots, n
$$

where, $\widetilde{g}(t)$ is the equivalent specific fuel consumption $(\mathrm{g} / \mathrm{kWh}) ; P_{L}(t)$ is the load power $(\mathrm{kW})$, $250 \mathrm{~kW} \leq P_{L}(t) \leq 700 \mathrm{~kW}$ according to the instructions given for the calculation of a ship's power load; $P_{D E}(t)$ is the diesel engine's power $(\mathrm{kW}) ; P_{N}(t)$ is the output power $(\mathrm{kW})$ of the new energy system (solar and battery); $g_{i}(t)$ is the current specific fuel consumption of the $i$ th diesel generator $(\mathrm{g} / \mathrm{kWh}) ; P_{o_{i}}(t)$ is the output power of the $i$ th diesel generator $(\mathrm{kW})$; and $\eta_{i}(t)$ is the efficiency of the $i$ th diesel generator.

With regard to the decrease in a ship's fuel consumption, it is necessary to ensure that diesel generators work at a higher efficiency in the long run, so that the engine remains in service for a long period. A diesel generator's efficiency is calculated by Equation (2) [36]:

$$
\eta_{i}(t)=\frac{3600 \cdot P_{O_{i}}(t)}{\rho_{f_{i}} \cdot Q_{i}(t) \cdot L H V}
$$

where $\rho_{f i}$ is the fuel density of the $i$ th diesel generator, setting $\rho_{f i}=820 \mathrm{~kg} / \mathrm{m}^{3} ; \mathrm{Q}_{\mathrm{i}}(\mathrm{t})$ denotes the fuel consumption of the $i$ th diesel generator $(\mathrm{kg} / \mathrm{h})$; and $L H V$ represents the lower heating value of the fuel, setting $L H V=43.2 . \mathrm{MJ} / \mathrm{kg}$

A diesel generator's fuel consumption can be expressed by Equation (3) [36]:

$$
Q_{i}(t)=a_{i}(t) \cdot P_{r_{i}}+b_{i}(t) \cdot P_{O_{i}}(t) \quad i=1,2, \cdots, n
$$

where, $a_{i}(t)$ and $b_{i}(t)$ represent the fuel intercept coefficient and fuel slope coefficient of the $i$ th diesel generator, which are 13.44 and $207.58 \mathrm{~g} / \mathrm{kWh}$ respectively; and $P_{r i}$ denotes the rated power of the $i$ th diesel generator $\left(P_{r 1}=P_{r 2}=1020 \mathrm{~kW}\right)$

Formula (4) can be obtained from Formulas (2) and (3):

$$
\eta_{i}(t)=\frac{3600 \cdot P_{O_{i}}(t)}{\rho_{f_{i}} \cdot\left(a_{i}(t) \cdot P_{r_{i}}+b_{i}(t) \cdot P_{O_{i}}(t)\right) \cdot L H V}
$$


In summary, the energy management strategy based on multi-objective optimization can be described by Equation (5):

$$
\begin{gathered}
\min \widetilde{g}(t)=\frac{\sum_{i=1}^{n} \frac{P_{O_{i}}(t)}{\eta_{i}(t)} \cdot g_{i}(t)}{P_{L}(t)} \\
\max \eta(t)=\frac{1}{n} \cdot \sum_{i=1}^{n} \frac{3600 \cdot P_{O_{i}}(t)}{\rho_{f_{i}} \cdot\left(a_{i}(t) \cdot P_{r_{i}}+b_{i}(t) \cdot P_{O_{i}}(t) \cdot L H V\right)} \\
\text { st. }\left\{\begin{array}{l}
P_{L}(t)=P_{N}(t)+\sum_{i=1}^{n} P_{O_{i}}(t) \quad i=1,2, \cdots, n \\
P_{N}(t)=P_{P V}(t)+P_{B a t}(t) \\
0 \leq P_{P V}(t) \leq 143 k W \\
250 k W \leq P_{L}(t) \leq 700 k W \\
P_{\text {min }} \leq P_{\text {Bat }}(t) \leq P_{\text {max }}
\end{array}\right.
\end{gathered}
$$

where, $P_{P V}(t)$ is the solar output power $(\mathrm{kW})$; and $P_{B a t}(t)$ is the battery power $(\mathrm{kW})$. When $P_{B a t}$ is positive, it means there is a discharge; when it is negative, it means there is a charge; $P_{\min }$ represents the battery's minimum output power, which is 0 ; and $P_{\max }$ denotes the battery's maximum output power as a restriction of the output power of the inverter, $P_{\max }$ set as $250 \mathrm{~kW}$.

In March 2016, we conducted tests on the parameters of the solar PV systems, batteries, diesel generator sets, and fuel consumption under the ship's different operating conditions. According to the experimental data, the relationship between the diesel generator's specific fuel consumption and the electric generator's power can be calculated, as illustrated in Figure 3.

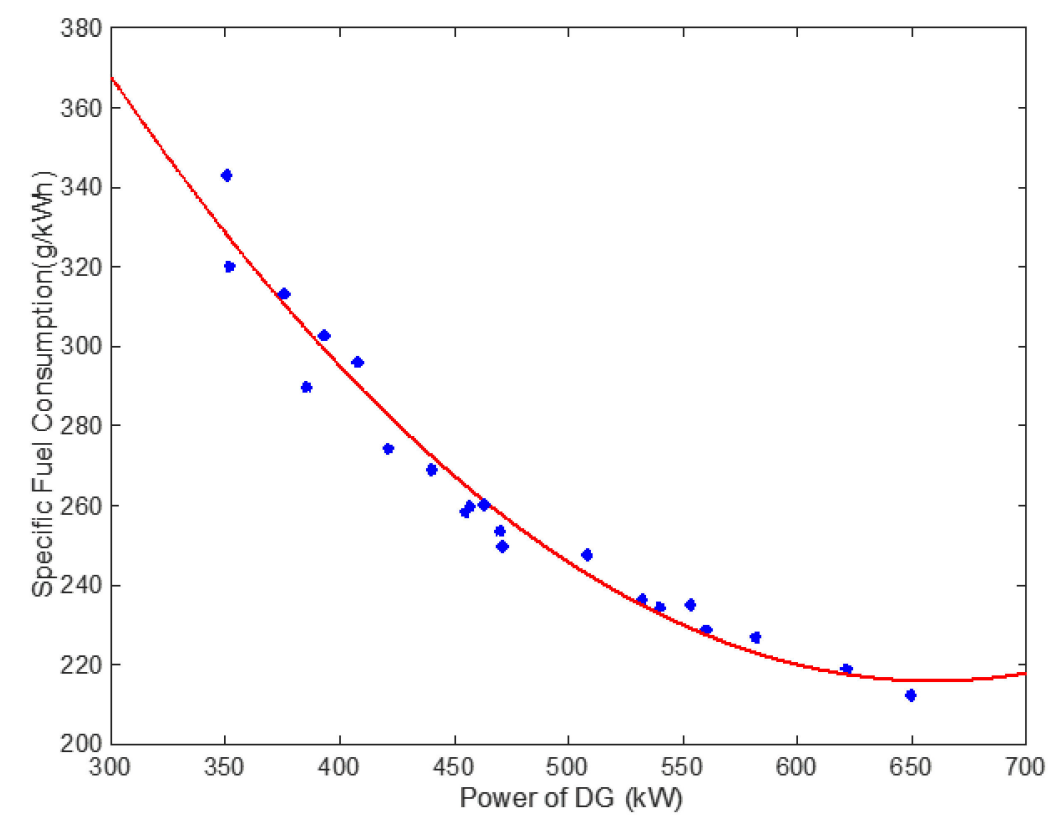

Figure 3. The curve of the specific fuel consumption as a function of an electric generator.

Using a polynomial fitting, the relationship between the diesel generator's specific fuel consumption and the electric generator's power can be obtained as follows:

$$
g_{i}(t)=f\left(P_{O_{i}}(t)\right)=727.86-1.55 \cdot P_{O_{i}}(t)+0.0012 \cdot\left(P_{O_{i}}(t)\right)^{2}
$$


Substituting Equation (6) into Equation (5), the multi-objective optimization is formulated by Equation (7):

$$
\begin{aligned}
& \min \widetilde{g}(t)=\frac{\sum_{i=1}^{n} \frac{P_{O_{i}}(t)}{\eta_{i}(t)} \cdot\left(727.86-1.55 \cdot P_{O_{i}}(t)+0.0012 \cdot\left(P_{O_{i}}(t)\right)^{2}\right)}{P_{L}(t)} \\
& \max \eta(t)=\frac{1}{n} \cdot \sum_{i=1}^{n} \frac{3600 \cdot P_{O_{i}}(t)}{\rho_{f_{i}} \cdot\left(a_{i}(t) \cdot P_{r_{i}}+b_{i}(t) \cdot P_{O_{i}}(t) \cdot L H V\right)} \\
& \text { st. }\left\{\begin{array}{l}
P_{L}(t)=P_{N}(t)+\sum_{i=1}^{n} P_{O_{i}}(t) \quad i=1,2, \cdots, n \\
P_{N}(t)=P_{P V}(t)+P_{B a t}(t) \\
0 \leq P_{P V}(t) \leq 143 k W \\
250 k W \leq P_{L}(t) \leq 700 k W \\
P_{\min } \leq P_{\text {Bat }}(t) \leq P_{\max }
\end{array}\right.
\end{aligned}
$$

\section{The PSO Algorithm}

Particle swarm optimization is an algorithm using the random search based on the cooperation of group, which is developed by simulating the foraging behavior of birds. The basic principle of PSO is to find the optimal solution through cooperation and the share of information among individuals in a certain group. The PSO algorithm is used extensively to solve multi-objective optimization problems in practical projects because of its rapid search speed, high efficiency, and simplicity [37]. Therefore, the PSO algorithm is used in this paper to solve the optimization problems related to the strategy of energy management. The algorithm's steps are as follows:

Step 1: Initialize N1-dimention particles with the output new energy power $P_{N}(\mathrm{t})$, and apply Equation (7) to calculate the fitness value of each particle. Then, an optimal value and optimal population value are calculated.

Step 2: Update the velocity and position of the particles. The updated equation is as follows [38]:

$$
\begin{gathered}
V^{k+1}=\omega V^{k}+c_{1} r_{1}\left(P_{i d}^{k}-X^{k}\right)+c_{2} r_{2}\left(P_{g d}^{k}-X^{k}\right) \\
X^{k+1}=X^{k}+V^{k+1}
\end{gathered}
$$

where, $\omega$ is the inertia weight; $r_{1}$ and $r_{2}$ represent the random numbers distributed in $[0,1] ; k$ denotes the current iteration number; $P_{i d}^{k}$ is the individual optimal particle position; $P_{g d}^{k}$ represents the global optimal particle position; $c_{1}$ and $c_{2}$ are constant; $V$ denotes the particle's velocity; and $X$ is the particle's position.

Step 3: Recalculate the fitness value of each particle satisfying the constraint of Equation (7). The individual optimal particle is updated according to the dominant relationship between the new particle and the current optimal particle.

Step 4: Repeat steps 2 and 3 until the algorithm converges. As a result, the optimal individual value can be obtained, that is, the optimal value of the new energy output power $P_{N}(\mathrm{t})$.

The relevant parameters selected by the PSO algorithm are shown in Table 2.

Table 2. The relevant parameters of the particle swarm optimization (PSO) algorithm.

\begin{tabular}{cccccc}
\hline$c_{1}$ & $c_{2}$ & $-\max$ & $-\min$ & xSize & MaxIt \\
\hline 2 & 2 & 0.9 & -1 & 50 & 4000 \\
\hline
\end{tabular}

\section{Results}

According to the multi-objective optimization model and numerical method referred to above, the non-inferior solution of the multi-objective optimization problem is formulated by programming. The distribution of the Pareto surface formed by these non-inferior solutions is illustrated in Figure 4 . 

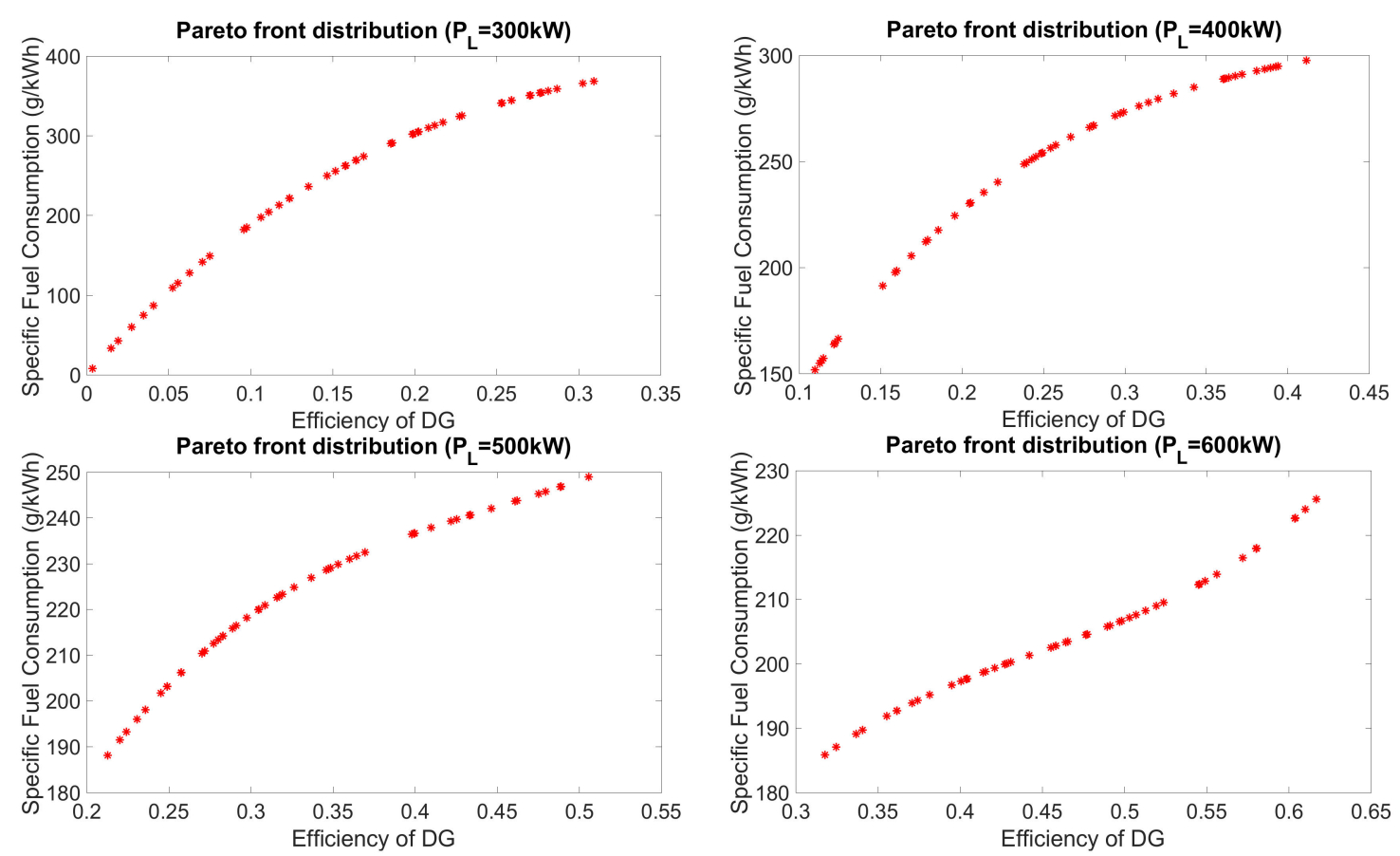

Figure 4. The distribution of non-inferior solutions for ships with different power loads.

As shown in Figure 4, the equivalent specific fuel consumption of the solar-diesel generator hybrid system increases with the increase in the diesel generators' efficiency, so the two optimization goals are mutually conflicting and restrictive. In order to simplify the analysis, Figure 5 shows the relationship between the output power of the new energy system and the spatial distribution of non-inferior solutions under different electrical loads.

It can be seen from Figure 5 that under different electrical loads, the ship's equivalent specific fuel consumption decreases as the new energy injected power increases, and the diesel generator's efficiency decreases accordingly. Therefore, the solar-diesel generator hybrid system can help to reduce the fuel consumption, although the ship's economic improvement will be at the expense of the diesel generator's efficiency. With the aid of the non-inferior solution for the multi-objective problem presented in this study, an optimal energy management strategy for the hybrid power system can be established. By reducing the ship's fuel consumption, the diesel generators should operate with a higher efficiency as much as possible, in order to prolong the engine's service life. In order to protect the battery from overcharging and discharging, the best range for the battery's state-of-charge (SOC) is between $30 \%-80 \%$.

1. When the battery's SOC is $\leq 30 \%$, the battery is in a state where it needs to be charged. Currently, the maximum power of the new energy connected to the grid is the solar energy's peak power, that is $P_{N \max }=143 \mathrm{~kW}$. Figure 6 shows the distribution of the non-inferior solution with $P_{N}$ in the region $(0,143 \mathrm{~kW})$. 

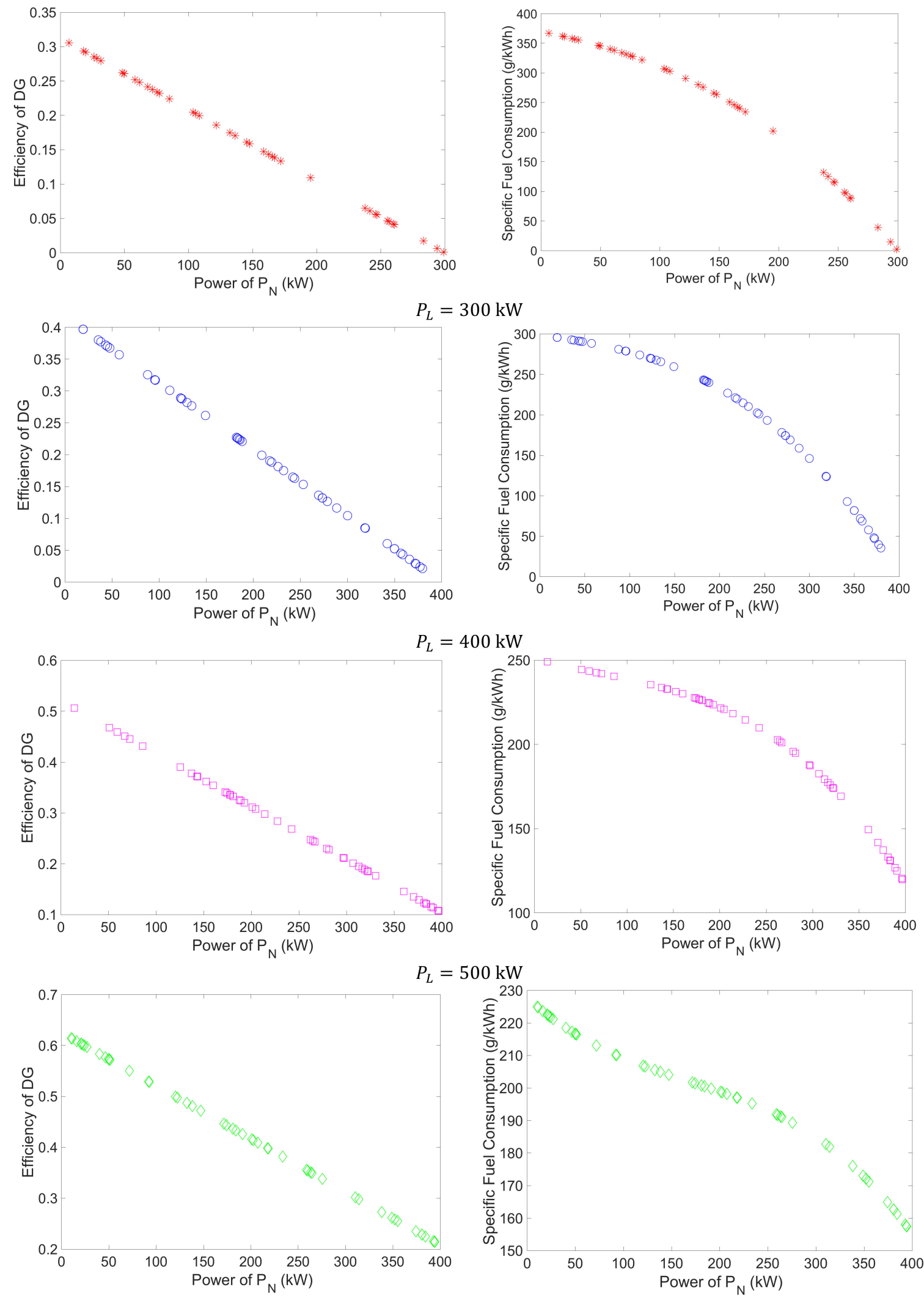

$P_{L}=600 \mathrm{~kW}$

Figure 5. The spatial distribution of non-inferior solutions under different electrical loads. 


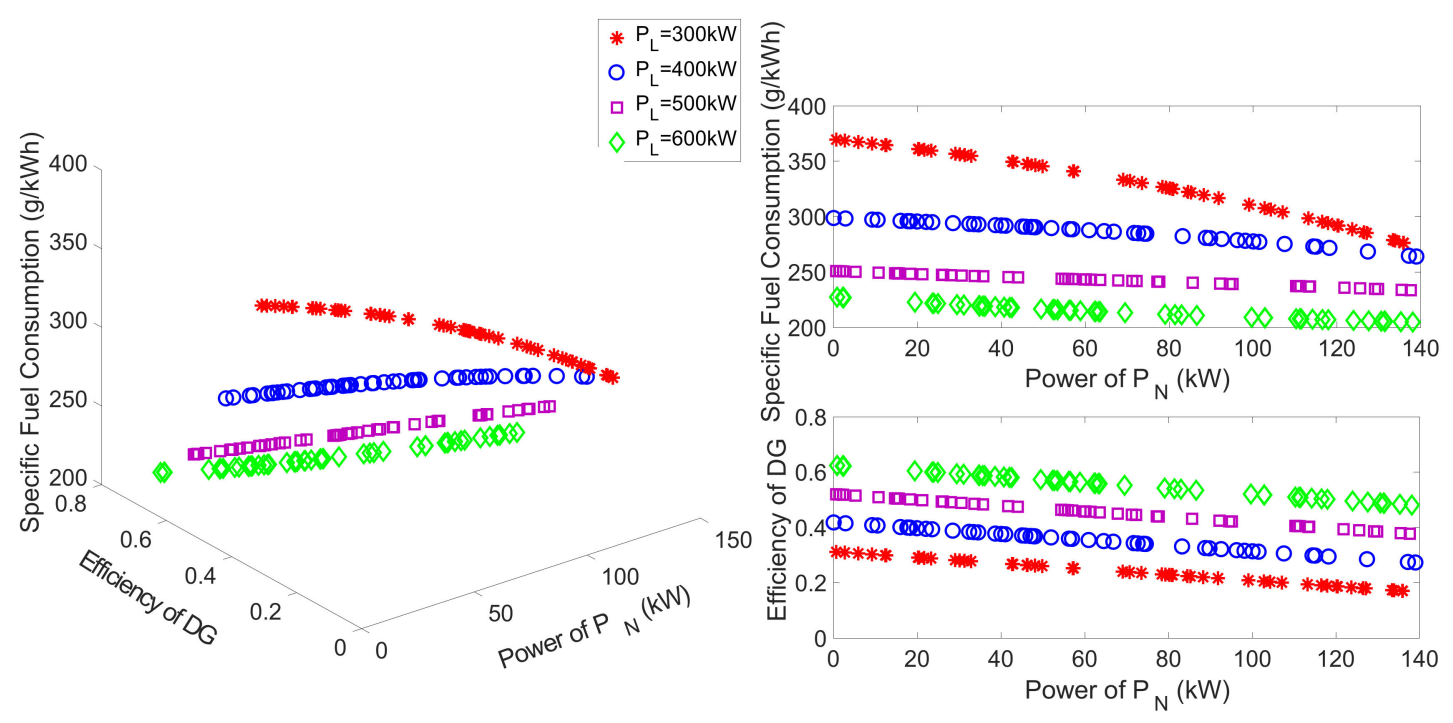

Figure 6. The non-inferior solution of $P_{N}$ in the range of $0-143 \mathrm{~kW}$

As shown in Figure 6, when the ship's electrical load is low, its equivalent specific fuel consumption decreases rapidly with the increase in solar power, but when the ship's electrical load is high, its equivalent specific fuel consumption decreases slowly with the increase in solar energy. However, regardless of the electrical load conditions, the diesel generators' efficiency decreases with the same trend as the injected solar power increases. When the solar power is the same, the higher the ship's electrical load, the lower the entire ship's equivalent specific fuel consumption, and the higher the diesel generator's efficiency. Thus, it can be concluded that when the ship's electrical load is high, its economy should mainly be considered, but when the ship's electrical load is low, full consideration should be given to the entire ship's fuel economy and the diesel generator's efficiency.

2 When the battery's SOC is $>30 \%$, the battery is in a state of discharging. At present, the maximum power required for a new energy injection is $390 \mathrm{~kW}$. Figure 7 displays the distribution of the non-inferior solution with $P_{N}$ in the range of $0-390 \mathrm{~kW}$.
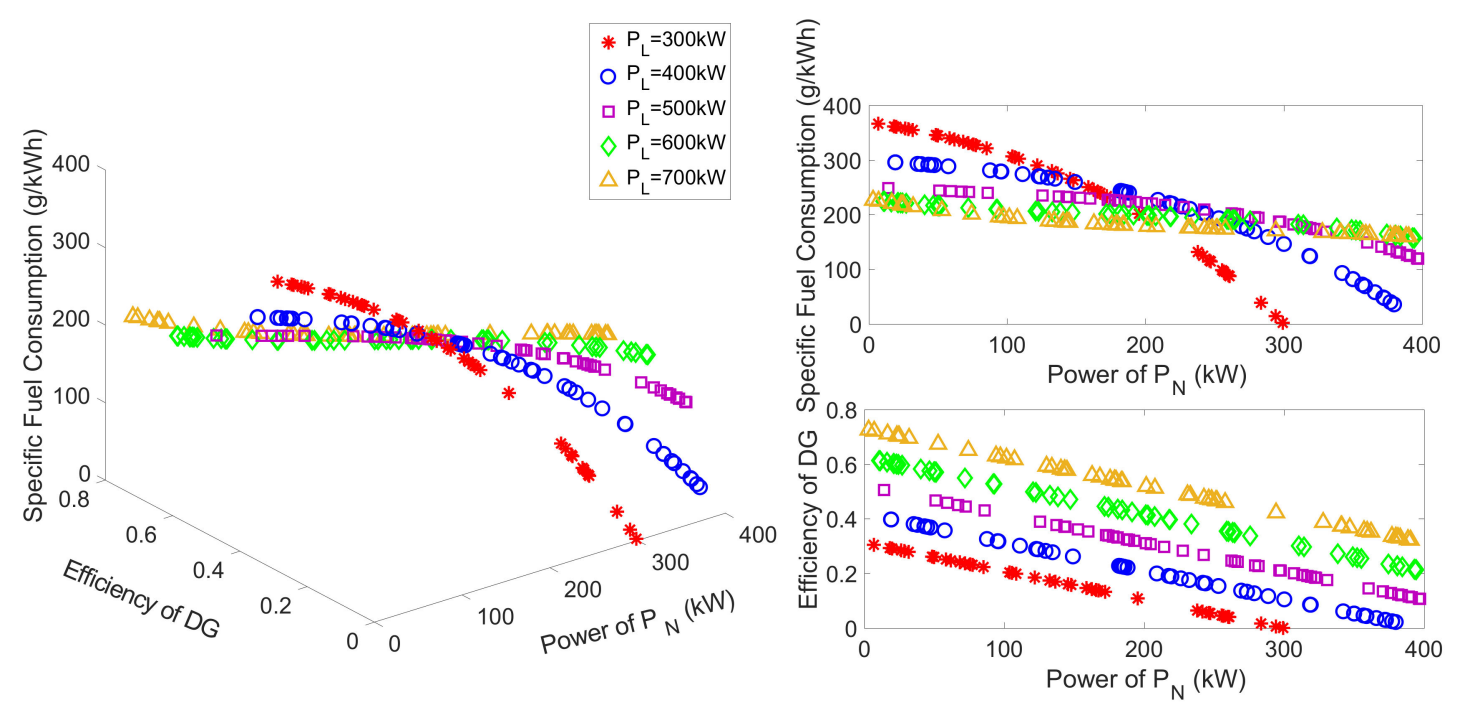

Figure 7. The distribution of non-inferior solution with $P_{N}$ in the range of 0-390 kW.

Generally, the entire ship's specific fuel consumption and the diesel generator's efficiency decrease with the increase in the new energy injection, with the diesel generator's efficiency basically following 
the same trend. The ship's specific fuel consumption shows a more pronounced decline trend when its electrical load is low. When the new energy injection increases from zero, the specific fuel consumption during a low electrical load is greater than that during a high electrical load. However, when the input power of new energy exceeds a critical value $\widetilde{P}_{N}$, the ship's specific fuel consumption during a low electrical load is lower than that during a high electrical load. When the injection power of new energy continues to increase, the specific fuel consumption declines rapidly, and the diesel generator's efficiency also decreases rapidly. When the injection power of the new energy is greater than the ship's electrical load, the diesel generator stops working. At this time, the new energy system provides power for the entire ship and the ship's economy is optimal. When the ship's electrical load is relatively high, e.g., $P_{L}=600 \mathrm{~kW}$ and $P_{L}=700 \mathrm{~kW}$, there is a slight difference in the specific fuel consumption with the same injection power of new energy. Hence, it can be concluded that when the ship's electrical load is less than the power injection of new energy, the new energy system should be given priority to power the ship. At this time, the entire ship has the optimal fuel economy. When the ship's electrical load is greater than the injection power of new energy and the load is high, the ship should be economically oriented and new energy should be injected as much as possible; if the load is low, the ship's economy and the diesel generator's efficiency must be fully considered.

According to the aforementioned optimization method, the output power of the new energy system has been optimized based on different loads. The optimization results are listed in Table 3 .

Table 3. The ship's specific fuel consumption and diesel generator's efficiency: experimental measurements versus optimization results.

\begin{tabular}{|c|c|c|c|c|c|c|c|c|c|c|c|c|}
\hline \multirow{3}{*}{$\begin{array}{l}\text { Power of } \\
\text { Load (kW) }\end{array}$} & \multicolumn{6}{|c|}{ When SOC $\leq 30 \%$} & \multicolumn{6}{|c|}{ When SOC>30\% } \\
\hline & \multicolumn{3}{|c|}{$\begin{array}{c}\text { Experimental } \\
\text { Measurements }\end{array}$} & \multicolumn{3}{|c|}{ Optimization Results } & \multicolumn{3}{|c|}{$\begin{array}{l}\text { Experimental } \\
\text { Measurements }\end{array}$} & \multicolumn{3}{|c|}{ Optimization Results } \\
\hline & $\begin{array}{c}P_{N} \\
(\mathbf{k W})\end{array}$ & $\begin{array}{c}\bar{g} \\
(\mathrm{~g} / \mathrm{kWh})\end{array}$ & $\eta$ & $\begin{array}{c}P_{N} \\
(\mathbf{k W})\end{array}$ & $\begin{array}{c}\bar{g} \\
(\mathrm{~g} / \mathrm{kWh})\end{array}$ & $\eta$ & $\begin{array}{c}P_{N} \\
(\mathbf{k W})\end{array}$ & $\begin{array}{c}\bar{g} \\
(\mathrm{~g} / \mathrm{kWh})\end{array}$ & $\eta$ & $\begin{array}{c}P_{N} \\
(\mathbf{k W})\end{array}$ & $\begin{array}{c}\bar{g} \\
(\mathrm{~g} / \mathrm{kWh})\end{array}$ & $\eta$ \\
\hline 300 & 130 & 281.8 & $17.64 \%$ & 100 & 285.2 & $21.32 \%$ & 80 & 327 & $23.1 \%$ & 300 & 0 & \\
\hline 400 & 121 & 272.5 & $27.8 \%$ & 115 & 272.1 & $29.6 \%$ & 220 & 288.78 & $11.58 \%$ & 202.5 & 159.8 & $25.4 \%$ \\
\hline 500 & 111.8 & 237.2 & $40.4 \%$ & 140 & 230.3 & $37.9 \%$ & 264 & 201.8 & $24.5 \%$ & 281.5 & 194.8 & $23.76 \%$ \\
\hline 600 & 117 & 207.2 & $50.3 \%$ & 140.8 & 201.1 & $47.8 \%$ & 359.1 & 164.5 & $35.5 \%$ & 393.8 & 157.5 & $33.2 \%$ \\
\hline
\end{tabular}

When the ship's electrical load is low and the battery's SOC is $\leq 30 \%$, it is necessary to reduce the power of the new energy generation system that is injected into the power grid, and improve the diesel generator's efficiency. For example, when the electrical load is $300 \mathrm{~kW}$, the injection power of the new energy system should be maintained at about $100 \mathrm{~kW}$. At this time, the diesel generator's efficiency is $21.32 \%$, which is higher than that before optimization. The equivalent specific fuel consumption is $285.2 \mathrm{~g} / \mathrm{kWh}$, which is not significantly higher than that before optimization. When the battery's SOC is $>30 \%$, the new energy generation system can fully meet the needs of the ship's electrical load. At this time, the diesel generator stops working and the new energy system supplies power to the ship. When the ship's electrical load is high, no matter whether the battery's SOC is large or small, its economy should be taken into account, and the injection power of the new energy system should be increased significantly. For instance, when the power load is $600 \mathrm{~kW}$ and the SOC is $<30 \%$, the injection power of the new energy system is $140.8 \mathrm{~kW}$. At this time, the ship's equivalent specific fuel consumption is $201.1 \mathrm{~g} / \mathrm{kWh}$, which is notably higher than that before optimization, and the diesel generator's efficiency is $47.8 \%$, which is not significantly lower than that before optimization.

The ship's average annual operation time is 365 days, which consist of 55 days in port and 310 days in normal navigation. According to the weather statistics for the ship's route, the solar PV system can work for about 292 days every year, including 44 days when the ship is in port and 248 days during normal navigation. According to the experimental data, when the ship is in port and during normal navigation, the power load is $600 \mathrm{~kW}$ for $90 \%$ of the time, and for the remaining $10 \%$ of the time it is between $300 \mathrm{~kW}$ and $500 \mathrm{~kW}$. This gives an average value of 400KW and average sunshine time of $6 \mathrm{~h}$ 
per day for calculation purposes. The ship's annual fuel consumption and $\mathrm{CO}_{2}$ emission are calculated as shown in Equations (9) and (10), respectively.

$$
\begin{gathered}
Q=\left(P_{L 1} \cdot \widetilde{g}_{1} \cdot 73 \cdot 90 \%+P_{L 2} \cdot \widetilde{g}_{2} \cdot 73 \cdot 10 \%\right) \cdot 24+\left(P_{L 1} \cdot \widetilde{g}_{1} \cdot 18+\left(P_{L 1}-P_{N 1}\right) \cdot \vec{g}_{1} \cdot 6\right) \cdot 292 \cdot 90 \%+ \\
\left(P_{L 2} \cdot \widetilde{g}_{2} \cdot 18+\left(P_{L 2}-P_{N 2}\right) \cdot \widetilde{g}_{2}^{\prime} \cdot 6\right) \cdot 292 \cdot 10 \% \\
q_{C O 2}=Q \times \alpha
\end{gathered}
$$

where $Q$ is the ship's annual fuel consumption (t); $P_{L i}(i=1,2)$ is theship's electrical load $(\mathrm{kW})$; $\widetilde{g}_{i}, \widetilde{g}_{i}^{\prime}(i=1,2)$ is the fuel consumption rate $(\mathrm{g} / \mathrm{kWh}) ; P_{N i}(i=1,2)$ is the power of the solar energy connected to the grid $(\mathrm{kW}) ; q_{c o 2}$ is the ship annual $\mathrm{CO}_{2}$ emission $(\mathrm{t})$; and $\alpha$ is the carbon emission coefficient, with a value of 3.175 .

According to Equations (9) and (10), the energy conservation and emission reduction results for one year using the PSO algorithm method are shown in Table 4.

Table 4. The effect on energy saving and reducing emission when the PSO algorithm method is used for one year.

\begin{tabular}{cccc}
\hline \multicolumn{2}{c}{ Experimental Measurements } & \multicolumn{2}{c}{ Optimization Results } \\
\hline fuel consumption $(\mathrm{t})$ & 1086.82 & fuel consumption $(\mathrm{t})$ & 1074.44 \\
\hline $\mathrm{CO}_{2}$ emission $(\mathrm{t})$ & 3450.66 & $\mathrm{CO}_{2}$ emission $(\mathrm{t})$ & 3411.35 \\
\hline efficiency of diesel generator & $39.05 \%$ & efficiency of diesel generator & $38.7 \%$ \\
\hline Fuel saving $(\mathrm{t})$ & & 12.38 \\
\hline Emission reduction $(\mathrm{t})$ & & 39.31 \\
\hline
\end{tabular}

Before optimization, when solar energy is used as much as possible, the ship consumes $1086.82 \mathrm{t}$ of fuel oil and produces $3450.66 \mathrm{t}$ of $\mathrm{CO}_{2}$ emissions per year. However, when the new energy source is connected to the power grid, the fuel consumption and $\mathrm{CO}_{2}$ emissions are $1074.44 \mathrm{t}$ and $3411.66 \mathrm{t}$, respectively, one year after using the $\mathrm{PSO}$ algorithm method. This saves $12.38 \mathrm{t}$ of fuel and $39.31 \mathrm{t}$ of $\mathrm{CO}_{2}$ compared to a year without using this method, and the diesel generator's efficiency is basically kept at the same level. Therefore, the PSO algorithm method can further reduce the ship's fuel consumption, and lead to the diesel generator operating in the range of appropriate efficiency.

\section{Conclusions}

This study aimed to improve the energy management of the solar-diesel hybrid generator system on a ship, and took the ship's economy and the diesel generators' efficiency into full consideration. A multi-objective optimization model was established, and the PSO algorithm was used to solve the model numerically. The major findings are outlined below.

\subsection{The Battery's SOC is $\leq 30 \%$}

When the ship's electrical load is relatively high, management of the system should be economically oriented, and the input of new energy should be increased appropriately. When the ship's electrical load is low, its fuel economy and the diesel generator's efficiency must be taken into account. For example, when the electrical load is $300 \mathrm{~kW}$, the solar power should be controlled at around $100 \mathrm{~kW}$.

\subsection{The Battery's SOC is $>30 \%$}

When $P_{L}<P_{N}$, it is preferable to use new energy to power the ship; when $P_{L} \geq P_{N}$ and the load is high, the injected new energy should be increased as much as possible. If the load is low, full consideration must be given to the ship's economy and diesel generator's efficiency. Therefore, it is preferable to use the solar energy. 
This method can be used in solar-diesel hybrid ships with a similar power distribution and different energy storage stations, i.e., medium and small-sized solar energy grid-connected power stations, and micro-grid systems.

Author Contributions: Conceptualization, Y.Y.; Methodology, T.L.; Software, R.Y.; Validation, R.Y.and B.S.; Formal Analysis, Y.Y. and R.Y.; Investigation, Y.Y.; Resources, Y.Y.; Data Curation, R.Y.;Writing-Original Draft Preparation, R.Y.; Writing-Review \& Editing, Y.Y. and B.S.; Funding Acquisition, Y.Y. All authors have read and agreed to the published version of the manuscript.

Funding: This research was funded by NSFC-Zhejiang Joint Fund for the Integration of Industrialization and Informatization grant number U1709215, Research Project of Advanced Technology Ship grand number MIIT [2016] 548, and the self-determined and innovative research funds of Wuhan University of Technology grant number 2018-ND-C1-19.

Conflicts of Interest: The authors declare no conflict of interest.

\section{References}

1. Lower emissions on the high seas. Nature 2017, 551, 5-6. [CrossRef]

2. Song, S.K.; Shon, Z.H.; Kim, Y.K.; Kang, Y.H.; Oh, I.B.; Jung, C. H Influence of ship emissions on ozone concentrations around coastal areas during summer season. Atmosphere Environ. 2010, 44, 713-723. [CrossRef]

3. Sofiev, M.; Winebrake, J.J.; Johansson, L.; Carr, E.; Prank, M.; Soares, J.; Vira, J.; Kounzetsov, R.D.; Jalkanen, J.P.; Corbett, J.J. Cleaner fuels for ships provide public health benefits with climate tradeoffs. Nat. Commun. 2018, 9, 406. [CrossRef] [PubMed]

4. De Cara, S.; Henry, L.; Jayet, P.A. Optimal coverage of an emission tax in the presence of monitoring, reporting, and verification costs. J. Environ. Econ. Manag. 2018, 89, 71-93. [CrossRef]

5. Lan, H.; Weng, S.L.; Hong, Y.Y.; Yu, D.C.; Zhang, L.J. Optimal sizing of hybrid PV/diesel/battery in ship power system. Appl. Energy 2015, 158, 26-34. [CrossRef]

6. Wen, S.L.; Lan, H.; Yu, D.C.; Fu, Q.; Hong, Y.Y.; Yu, L.J.; Yang, R.R. Optimal sizing of hybrid energy storage sub-systems in PV/Diesel ship power system using frequency analysis. Energy 2017, 140, 198-208. [CrossRef]

7. Lee, K.J.; Shin, D.S.; Yoo, D.W.; Choi, H.K.; Kim, H.J. Hybrid photovoltaic/diesel green ship operating in standalone and grid-connected mode-Experimental investigation. Energy 2013, 49, 475-483. [CrossRef]

8. Bernardi, M.; Ferralis, N.; Wan, J.H.; Villalon, R.; Grossman, J. Solar Energy Generation in Three Dimensions. Energy Environ. Sci. 2012, 5, 6880-6884. [CrossRef]

9. Tang, X.J.; Wang, T.; Zhi, C.; Huang, Y.M. The design of power management system for solar ship. In Proceedings of the 2015 International Conference on Transportation Information and Safety (ICTIS), Wuhan, China, 25-28 June 2015; IEEE: Piscataway, NJ, USA, 2015; pp. 548-553.

10. Diab, F.; Lan, H.; Ali, S. Novel comparison study between the hybrid renewable energy systems on land and on ship. Renew. Sustain. Energy Rev. 2016, 63, 452-463. [CrossRef]

11. Yan, R.F.; Saha, T.K.; Modi, N.; Masood, N.A.; Mosadeghy, M. The combined effects of high penetration of wind and PV on power system frequency response. Appl. Energy 2015, 145, 320-330. [CrossRef]

12. Balcombe, P.; Dan, R.; Azapagic, A. Environmental impacts of microgeneration: Integrating solar PV, Stirling engine CHP and battery storage. Appl. Energy 2015, 139, 245-259. [CrossRef]

13. Erdinc, O.; Uzunoglu, M. Recent trends in PEM fuel cell-powered hybrid systems: Investigation of application areas, design architectures and energy management approaches. Renew. Sustain. Energy Rev. 2010, 14, 2874-2884. [CrossRef]

14. Maheri, A. Multi-objective design optimization of standalone hybrid wind-PV-diesel systems under uncertainties. Renew. Energy 2014, 66, 650-661. [CrossRef]

15. Uzunoglu, M.; Onar, O.C.; Alam, M.S. Modeling, control and simulation of a PV/FC/UC based hybrid power generation system for stand-alone applications. Renew. Energy 2009, 34, 509-520. [CrossRef]

16. Onar, O.C.; Uzunoglu, M.; Alam, M.S. Modeling, control and simulation of an autonomous wind turbine/photovoltaic/fuel cell/ultra-capacitor hybrid power system. J. Power Sour. 2008, 185, 1273-1283. [CrossRef]

17. Sichilalu, S.; Mathaba, T.; Xia, X. Optimal control of a wind-PV-hybrid powered heat pump water heater. Appl. Energy 2015, 185, 1173-1184. [CrossRef] 
18. Erdinc, O.; Elma, O.; Uzunoglu, M.; Selamogullari, U.S.; Vural, B.; Ugur, E.; Boynuegri, A.R.; Dusmez, S. Experimental performance assessment of an online energy management strategy for varying renewable power production suppression. Int. J. Hydrog. Energy 2012, 37, 4737-4748. [CrossRef]

19. Bigdeli, N. Optimal management of hybrid PV /fuel cell/battery power system: A comparison of optimal hybrid approaches. Renew. Sustain. Energy Rev. 2015, 42, 377-393. [CrossRef]

20. Li, F.F.; Qiu, J. Multi-objective optimization for integrated hydro-photovoltaic power system. Appl. Energy 2016, 167, 377-384. [CrossRef]

21. Mahmood, H.; Michaelson, D.; Jiang, J. Decentralized Power Management of a PV/Battery Hybrid Unit in a Droop-Controlled Islanded Microgrid. IEEE Trans. Power Electron. 2015, 30, 7215-7229. [CrossRef]

22. Choudar, A.; Boukhetala, D.; Barkat, S.; Brucker, J.M. A local energy management of a hybrid PV -storage based distributed generation for microgrids. Energy Convers. Manag. 2015, 90, 21-33. [CrossRef]

23. Tummuru, N.R.; Mishra, M.K.; Srinivas, S. Dynamic Energy Management of Hybrid Energy Storage System with High-Gain PV Converter. IEEE Trans. Energy Convers. 2015, 30, 150-160. [CrossRef]

24. Maleki, A.; Ameri, M.; Keynia, F. Scrutiny of multifarious particle swarm optimization for finding the optimal size of a PV/wind/battery hybrid system. Renew. Energy 2015, 80, 552-563. [CrossRef]

25. Mohanty, A.; Patra, S.; Ray, P.K. Robust fuzzy-sliding mode based UPFC controller for transient stability analysis in autonomous wind-diesel-PV hybrid system. IET Gener. Transm. Distrib. 2016, 10, 1248-1257. [CrossRef]

26. Ren, H.B.; Wu, Q.; Gao, W.J.; Zhou, W.S. Optimal operation of a grid-connected hybrid PV/fuel cell/battery energy system for residential applications. Energy 2016, 113, 702-712. [CrossRef]

27. Liu, H.D.; Zhang, Q.; Qi, X.X.; Han, Y.; Lu, F. Estimation of PV output power in moving and rocking hybrid energy marine ships. Appl. Energy 2017, 204, 362-372. [CrossRef]

28. Guo, C.; Sun, Y.W.; Yuan, C.C.; Yan, X.P.; Wang, Y.; Jiang, Q.Z. Research on power load flow calculation for photovoltaic-ship power system based on PSAT. In Proceedings of the 2015 International Conference on Renewable Energy Research and Applications (ICRERA), Palermo, Italy, 22-25 November 2015; IEEE: Piscataway, NJ, USA, 2015; pp. 443-448.

29. Kenan, Y.; Bora, A. A new electrical energy management approach for ships using mixed energy sources to ensure sustainable port cities. Sustain. Cities Soc. 2018, 40, 126-135. [CrossRef]

30. Cao, T.; Lee, H.; Hwang, Y.H.; Radermacher, R. Modeling of Hybrid Cooling Systems for Shipboard Application. In Proceedings of the ASME 2014 International Conference on Energy Sustainability Collocated with the ASME 2014 International Conference on Fuel Cell Science, Engineering and Technology, Boston, MA, USA, 30 June 2014-2 July 2014. V002T10A001-V002T10A001.

31. Park, J.S.; Katagi, T.; Yamamoto, S.; Hashimoto, T. Operation control of photovoltaic/diesel hybrid generating system considering fluctuation of solar radiation. Sol. Energy Mater. Sol. Cells 2001, 67, 535-542. [CrossRef]

32. Lan, H.; Bai, Y.F.; Wen, S.L.; Yu, D.; Hong, Y.Y.; Dai, J.F.; Cheng, P. Modeling and Stability Analysis of Hybrid PV/Diesel/ESS in Ship Power System. Inventions 2016, 1, 5. [CrossRef]

33. Divyajot, Kumar, R.; Fozdar, M. Optimal sizing of hybrid ship power system using variants of particle swarm optimization. In Proceedings of the 2017 Recent Developments in Control, Automation \& Power Engineering (RDCAPE), Noida, India, 26-27 October 2017; IEEE: Piscataway, NJ, USA, 2017; pp. 527-532.

34. Zhang, W.; Shi, W.; Zhuo, J. Shipboard power system stabilizer optimization using GA and QPSO algorithm. Int. J. Comput. Intell. Appl. 2017, 16, 50-65. [CrossRef]

35. Mashadi, B.; Emadi, S.A.M. Dual-Mode Power-Split Transmission for Hybrid Electric Vehicles. IEEE Trans. Vehic. Technol. 2010, 59, 3223-3232. [CrossRef]

36. Ramli, M.A.M.; Hiendro, A.; Twaha, S. Economic analysis of PV/diesel hybrid system with flywheel energy storage. Renew. Energy 2015, 78, 398-405. [CrossRef]

37. Tassopoulos, I.X.; Beligiannis, G.N. Solving effectively the schooltimetabling problem using particle swarm optimization. Expert Syst. Appl. 2012, 39, 6029-6040. [CrossRef]

38. Ting, C.J.; Wu, K.C.; Chou, H. Particle swarm optimization algorithm for the berth allocation problem. Expert Syst. Appl. 2014, 41, 1543-1550. [CrossRef]

(C) 2020 by the authors. Licensee MDPI, Basel, Switzerland. This article is an open access article distributed under the terms and conditions of the Creative Commons Attribution (CC BY) license (http://creativecommons.org/licenses/by/4.0/). 